\title{
Report Comparative Study on the Environmental Education Acts in Japan, Taiwan, and Korea
}

\author{
Masahiro Saito*, Hideki Sato**, Tzuchau Chang***, Chankook Kim****, \\ Kochi University, Japan*, Japan Environmental Education Forum (JEEF), Japan**, \\ National Taiwan Normal University, Taiwan***, Korea National University of Education, Korea****,
}

Accepted on June 3, 2019

\begin{abstract}
There are eight countries in the world that have enacted the Environmental Education Acts (hereinafter referred to as "EEAs") as of 2019. Of these, three countries in East Asia-Japan, Taiwan, and Korea-established the EEAs and they conduct pioneering efforts around the world. In Japan, the EEAs was enacted in 2003 and revised in 2011. In Korea, it was enacted in 2008 and revised in 2015. In Taiwan, it was promulgated in 2010 and put into effect in 2011.

When we look at trends in previous studies in Japan, international comparative studies of the management of environmental administrations and the EEAs are not really investigated in the previous studies. We think this is because the contents and characteristics of specific systems indicated in the individual articles of the EEAs are not provided in these international comparative studies.

The purpose of this study is to compare the EEAs in Japan, Taiwan, and Korea, to clarify the institutional issues of the EEAs in the three countries. In this paper, as a first step, we would like to clarify the similarities and differences in the management of the systems for the promotion, support, and provision of participation opportunities in environmental education in each country.

We organized the similarities and differences of the EEAs in the three countries. We found that the similarities included the fact that participation and collaboration by various actors were emphasized in the purpose,the definition of environmental education, and the basic policies and plans of nations and municipalities. On the other hand, differences could be found in the legally binding nature of the EEAs. We therefore propose a hypothesis that there are differences among the three countries in the roles of administrations in promoting environmental education. Based on this, we offer further areas of study to clarify the comparative studies.
\end{abstract}

Keywords: Comparative Study, Environmental Administration, Environmental Education, Environmental Education Acts (EEAs), Legally Binding

\section{Introduction}

There are eight countries in the world that have enacted the Environmental Education Acts (hereinafter referred to as "EEAs") as of $2019^{1)}$. Of these, three countries in East Asia-Japan, Taiwan and Korea-established the EEAs and they conduct pioneering efforts around the world. In Japan, the EEAs was enacted in 2003 and revised in 2011. In Republic of Korea (South Korea, hereinafter referred to as "Korea"), it was enacted in 2008 and revised in 2015. In Taiwan, it was promulgated in 2010 and made effective in 2011.

When we look at trends in international comparative studies in Japan, many of them clarify characteristics of the EEAs in each country. At the same time, international comparative studies of the management of environmental administrations and the EEAs are less well understood (Takahashi and Imura 2005, Ota 2009, Japan Institute of Business Law 2017). We think this is because the contents and characteristics of specific systems indicated in the individual articles of the EEAs are not provided in these international comparative studies.

Moreover, in the summary of the International Collaborative Research Project of the Japanese Society for Environmental Education (JSFEE) for 2017 (Ninomiya-lim et al. 2017), it has been proposed that "one of the next steps for further study should be to investigate the possible impacts of institutionalization on the characteristics, content, and quality of non-formal environmental education in Asia". Therefore, we think that the study covered in this paper will lead to advancements in this project by clarifying the operation and the problems of systems described in the EEAs of Asia.

Email: m-saito@kochi-u.ac.jp 
The purpose of this study is to compare the management of EEAs in Japan, Taiwan, and Korea, and to clarify the institutional issues of EEAs in the three countries. As a first step for our study, this paper compares the EEAs among three countries. And we would like to clarify the similarities and differences in the systems for the promotion, support, and provision of participation opportunities in environmental education in each country.

The contents of this paper are as follows: In Section II, we summarize an overview of the EEAs and its characteristics in the three countries ${ }^{2}$. Section III compiles the similarities and differences of the EEAs in the three countries. The final section provides the research results and offer areas for further comparative study.

\section{Overview and Characteristics of the Environmental Education Acts in Japan, Taiwan, and Korea}

\section{Outline of the Environmental Education Acts in Japan, Taiwan, and Korea}

Table 1 shows the content of the provisions of the EEAs in Japan, Taiwan, and Korea, and compares the framework of the Acts in the three countries. The three countries share having the provisions of the purpose, definitions, and action plans for environmental education. Japan and Taiwan Acts are composed of chapters or clauses in the constitution, while they are not included in the Korean Act. However, when we compare the articles, the provisions of general provisions, basic policies, and plans have commonalities with three countries.

In particular, Chapter 3 in Japan, Chapter 3 and Chapter 4 in Taiwan, and the provisions from "Support for Environmental Education in Schools" (Article 9) to "Designation of the Environmental Education Center" (Article 16) in Korea have unique characteristics in each of the three countries. An overview of the EEAs and the characteristics in Japan, Taiwan, and Korea will be introduced in this section.

Table 1 Comparing the Outline of the Environmental Education Acts in Japan, Taiwan, and Korea

\begin{tabular}{|c|c|c|c|c|c|}
\hline \multicolumn{3}{|c|}{ EEAs in Japan } & \multicolumn{2}{|c|}{ EEAs in Taiwan } & \multirow[t]{2}{*}{ EEAs in Korea } \\
\hline \multirow{4}{*}{\multicolumn{2}{|c|}{ Chapter I General Provisions }} & Purpose & \multirow{4}{*}{$\begin{array}{c}\text { Chapter I } \\
\text { General Principles }\end{array}$} & Purpose & \\
\hline & & Definitions & & \multirow{3}{*}{\begin{tabular}{l|l} 
Competent Authority & \\
Definitions & \\
Targets of Environmental \\
Education
\end{tabular}} & \multirow{2}{*}{$\begin{array}{l}\text { Definitions } \\
\text { Relationship With Other Acts }\end{array}$} \\
\hline & & \multirow{2}{*}{$\begin{array}{l}\text { Basic Principles } \\
\text { Responsibilities of Citizens and Private } \\
\text { Organizations, State, and Local Governments }\end{array}$} & & & \\
\hline & & & & & \multirow{2}{*}{\begin{tabular}{|l|} 
Duties \\
Formulation of Comprehensive Plans on \\
Environmental Education
\end{tabular}} \\
\hline \multirow{4}{*}{\multicolumn{2}{|c|}{ Chapter II Basic Policy, etc. }} & Basic Policy & \multirow{3}{*}{$\begin{array}{l}\text { Chapter II } \\
\text { Environmental } \\
\text { Education Policy }\end{array}$} & $\begin{array}{l}\text { National Environmental } \\
\text { Education Outline }\end{array}$ & \\
\hline & & $\begin{array}{l}\text { Action Plan of Prefectural and Municipal } \\
\text { Governments }\end{array}$ & & $\begin{array}{l}\text { National Environmental } \\
\text { Education Action Plan }\end{array}$ & $\begin{array}{l}\text { Implementation of Comprehensive Plans on } \\
\text { Environmental Education }\end{array}$ \\
\hline & & $\begin{array}{l}\text { Council for the Promotion of Environmental } \\
\text { Education }\end{array}$ & & $\begin{array}{l}\text { Local Environmental } \\
\text { Education Action Plans }\end{array}$ & $\begin{array}{l}\text { Establishment and Operation of the } \\
\text { Environmental Education Promotion } \\
\text { Committee }\end{array}$ \\
\hline & & Proposal for the Creation of the Action Plan & & & $\begin{array}{l}\text { Requests for Cooperation From Public } \\
\text { Institutions }\end{array}$ \\
\hline \multirow{11}{*}{$\begin{array}{l}\text { Chapter III Promotion } \\
\text { of Environmental } \\
\text { Conservation } \\
\text { Activities by Citizens }\end{array}$} & \multirow{6}{*}{$\begin{array}{l}\text { Section } 1 \\
\text { Encouraging } \\
\text { Participation in } \\
\text { Environmental } \\
\text { Conservation and } \\
\text { Environmental } \\
\text { Education }\end{array}$} & $\begin{array}{l}\text { Support Concerning Environmental Education in } \\
\text { School Education }\end{array}$ & \multirow{7}{*}{$\begin{array}{l}\text { Chapter III Powers } \\
\text { and Responsibilities } \\
\text { of Environmental } \\
\text { Education Agencies }\end{array}$} & $\begin{array}{l}\text { Compilation of Budgets and } \\
\text { Establishment of a Fund for } \\
\text { Environmental Education }\end{array}$ & $\begin{array}{l}\text { Support for Environmental Education in } \\
\text { Schools }\end{array}$ \\
\hline & & $\begin{array}{l}\text { Encouraging Participation in Environmental } \\
\text { Conservation and Environmental Education at the } \\
\text { Workplace }\end{array}$ & & How to use the fund & $\begin{array}{l}\text { Promotion of Non-Formal Environmental } \\
\text { Education }\end{array}$ \\
\hline & & $\begin{array}{l}\text { Supporting Organizations of Environmental } \\
\text { Education }\end{array}$ & & $\begin{array}{l}\text { C e r t if ic a t i o n s of } \\
\text { Environmental Education } \\
\text { Agencies and Environmental } \\
\text { Education Personnel }\end{array}$ & $\begin{array}{l}\text { Non-Formal Environmental Education } \\
\text { Educators }\end{array}$ \\
\hline & & Human Resource Certification Services & & $\begin{array}{l}\text { National Environmental } \\
\text { Education Review Committee }\end{array}$ & $\begin{array}{l}\text { Training Institutions for Non-Formal } \\
\text { Environmental Education Educators }\end{array}$ \\
\hline & & $\begin{array}{l}\text { Development of System with Functions as the Base } \\
\text { for Encouraging Participation in Environmental } \\
\text { Conservation }\end{array}$ & & $\begin{array}{l}\text { Local Environmental } \\
\text { Education Review Committees }\end{array}$ & $\begin{array}{l}\text { Development, Distribution, and Certification } \\
\text { of Environmental Education Programs }\end{array}$ \\
\hline & & Certification of Places for Nature-Based Experiences, etc. & & \begin{tabular}{l|} 
Designation of Environmental \\
Education Agencies and Personnel
\end{tabular} & $\begin{array}{l}\text { Environmental Education Program Certification } \\
\text { Examination Committee }\end{array}$ \\
\hline & \multirow{5}{*}{$\begin{array}{l}\text { Section } 2 \text { Promotion } \\
\text { of Collaborative } \\
\text { Efforts }\end{array}$} & Dissemination of Roles for Collaborative Efforts & & $\begin{array}{l}\text { Duties of Competent Authorities } \\
\text { at All Levels, Education } \\
\text { Competent Authorities at All } \\
\text { Levels, Central Competent } \\
\text { Authority, Central Industry } \\
\text { Competent Authorities }\end{array}$ & $\begin{array}{l}\text { Revoking Certification of Environmental } \\
\text { Education Programs } \\
\end{array}$ \\
\hline & & Reflection of Public Opinions in Policy Formation & \multirow{3}{*}{$\begin{array}{l}\text { Chapter IV } \\
\text { Environmental } \\
\text { Education Promotion } \\
\text { and Incentives }\end{array}$} & $\begin{array}{l}\text { Making environmental education } \\
\text { promotion compulsory }\end{array}$ & \multirow{4}{*}{$\begin{array}{l}\text { Designation of the Environmental Education } \\
\text { Center }\end{array}$} \\
\hline & & $\begin{array}{l}\text { Expansion of Opportunities for Private Organizations to } \\
\text { Enter the Public Service Sector }\end{array}$ & & $\begin{array}{l}\text { Assistance and Reward of } \\
\text { Environmental Education }\end{array}$ & \\
\hline & & Execution of Agreements on Environmental Conservation & & $\begin{array}{l}\text { Strengthening Environmental } \\
\text { Education-related Research }\end{array}$ & \\
\hline & & Provision of Information for Collaborative Efforts & & & \\
\hline \multirow{5}{*}{\multicolumn{2}{|c|}{ Chapter IV Miscellaneous Provisions }} & $\begin{array}{l}\text { Promotion of Public Action Giving Consideration to } \\
\text { Environmental Conservation Through a System Under } \\
\text { Which Economic Value is Added }\end{array}$ & \multirow[t]{2}{*}{$\begin{array}{c}\text { Chapter V } \\
\text { Penal Provisions }\end{array}$} & \multirow[t]{2}{*}{ Penal Provisions } & Subsidizing Expenses \\
\hline & & Financial Measures & & & Delegation or Entrustment of Authority \\
\hline & & Active Publication of Information & \multirow{3}{*}{$\begin{array}{l}\text { Chapter VI } \\
\text { Supplementary } \\
\text { Provisions }\end{array}$} & \multirow{3}{*}{ Supplementary Provisions } & Hearings \\
\hline & & Conference for the Promotion of Environmental Education & & & Administrative Fines \\
\hline & & Competent Minister & & & \\
\hline
\end{tabular}




\section{The Act on the Promotion of Environmental Conservation Activities Through Environmental Education in Japan}

The "Act for Enhancing Motivation of Environmental Conservation and Promoting Environmental Education" was enacted by lawmaker-initiated legislation in July 2003. Five ministries have jurisdiction over this Act: the Ministry of Education, Culture, Sports, Science and Technology; the Ministry of Economy, Trade and Industry; the Ministry of Agriculture, Forestry and Fisheries; the Ministry of Land, Infrastructure, Transport and Tourism; and the Ministry of the Environment. In June 2011, it was revised out of the necessity to cultivate human resources who acquire wide and practical capacities in environment conservation. The revisions included reflecting collaborative activities with multi-stakeholders related to the environment conservation and growing the needs of environmental education (hereinafter referred to as "EE") in schools. The title was also changed to "Act on the Promotion of Environmental Conservation Activities through Environmental Education" (hereinafter referred to as "APEE").

This Act is composed of four chapters and two sections as follows;

- Chapter I: General Provisions (Articles 1 to 6)

- Chapter II: Basic Policy, etc. (Articles 7 to 8-3)

- Chapter III: Promotion of Environmental Conservation Activities by Citizens

Section 1 -Encouraging Participation in Environmental Conservation and Environmental Education (Articles 9 to $20-10)$

Section 2 -Promotion of Collaborative Efforts (Articles 21 to 21-6)

- Chapter IV: Miscellaneous Provisions (Articles 22 to 28)

It is supposed to be reviewed within a five-year target period. Below, we expound the main points of the Act.

\section{1) Chapter I: General Provisions (Articles 1 to 6)}

This chapter establishes the Purpose (Article 1), Definitions (Article 2), Basic Principles (Article 3), and Responsibilities of Citizens, Private Organizations, the State, prefectures and Local Governments (Articles 4, 5, 6), etc.

The basic principles on the importance and collaborative efforts of environmental conservation activities, encouraging participation in environmental conservation, and EE for establishing a sustainable society is prescribed in Article 1. In addition, the responsibilities of citizens, private organizations, the state, and local governments are clarified here, and the basic policy and other necessary particulars are also established. Thereby, Article 1 aims to contribute to ensure healthy and culturally meaningful lives for citizens of both the present and future generations.

The definitions are specified in Article 2, and the term "Environmental Education" as used in this Act aims to establish a sustainable society with a deep understanding of the extensive links between the environment and society, the economy, and culture.

Article 3 is clarified to be conducted under mutual cooperation between an equal footing in society, conserving and coexisting with rich nature, establishing a sound recycle-oriented society, respecting the importance of promoting environmental conservation and an economy and society in an integrated manner, and honoring the voluntary ownership of citizens and private organizations. The article is also focused on nurturing attitudes to value life, treasure nature, and contributing to environmental conservation through hands-on experience. Moreover, this article contains content on considering conservation of national land, the harmonization of industries, the stability of local people's lives, and the successive respect for culture and history.

Responsibilities of citizens, private organizations, the state and local governments are described in the Articles 4, 5, and 6. In particular, included is the fact that citizens and private organizations should voluntarily conduct EE at home, in schools, and in local communities, etc., and the state and local governments are to implement measures concerning EE with shared mutual roles, etc.

\section{2) Chapter II: Basic Policy, etc. (Articles 7 to 8-3)}

This chapter is characterized by the stipulation of the Basic Policy (Article 7) and Action Plan of Prefectural and Municipal Governments (Article 8). 
In Article 7, the state has to establish the basic policy for promoting environmental conservation activities, encouraging participation in environmental conservation, EE, and collaborative efforts.

In Article 8, the prefectural and municipal governments may organize a Council for the Promotion of Environmental Education, etc. in order to make the Action Plan.

\section{3) Chapter III: Promotion of Environmental Conservation Activities by Citizens}

(1) Section 1 -Encouraging Participation in Environmental Conservation and Environmental Education (Articles 9 to 20-10)

An important point here is the stipulation of the framework for the fulfillment of the implementation of EE in school education (Article 9), for the reinforcement of EE foundation (Articles10-2, 11) and for the promotion of hands-on experience (Article 20).

Sufficiently implementing EE in school education is described in Article 9. In order to systematically promote EE in each stage of growth, it is necessary to take measures to improve the quality of teachers, and to provide informational materials for reference purposes and to develop educational materials. It is also necessary to set up, maintain, and make the most of eco-schools, and to consider environmentally friendly actions in school facilities.

In Article 10-2, the state designates a non-profit organization as a supporting organization of EE.

In Article 11, which covers the registration of human resource certification, the state must register and publish projects on certification concerning cultivating EE leaders and developing the EE materials that private organizations implement.

Article 20 mentions the certification of opportunities for hands-on experiences, as well as how prefectural governors prescribe the certification of safety requirements for the nature-based opportunities that land owners, etc., provide.

(2) Section 2 - Promotion of Collaborative Efforts (Articles 21 to 21-6)

The promotion of collaborative efforts is stipulated in Article 21. In particular, in Articles 21-4 and 21-5, diverse bodies including the state and the local governments, citizens, and private organizations, etc. can execute agreements for collaborative efforts on environmental conservation.

\section{4) Chapter IV: Miscellaneous Provisions (Articles 22 to 28)}

In Article 22, the state and local governments are to promote environmentally friendly conservation actions by citizens by building the mechanisms through which economic value is added. In particular, it is clarified that they take financial or tax-related measures to effectively implement the certified field for nature-based experiences and to develop human resources for environmental conservation in the collaborative efforts, and honor exceptional contributors, etc.

Finally, summarizing the characteristics of the APEE in Japan, it is concluded that the APEE aims to emphasize the roles of multi-stakeholders such as the state and local governments, enterprises, schools, NGO/ NPOs, and citizens, reinforce the EE base, collaborative efforts and hands-on experience, and to build a sustainable society by widely developing human resources by being focused on the links between the economy, society, the environment, and culture.

\section{Environmental Education Act in Taiwan}

\section{1) The history of environmental education legislation in Taiwan}

The EEAs was discussed in 1992. According to the "Five Years Middle-Term Projects for Environmental Education", the central government shall establish an EEAs. Research on the Environmental Education Act in Taiwan (hereinafter referred to as "TEEA") had been ongoing for over 18 years and the draft has been revised over 20 times. Finally, the TEEA was passed on June 5th, 2010 and put into effect the next year on June 5th, 2011. 


\section{2) The aims of the TEEA}

The TEEA is composed of five chapters. These include general principles, EE policy, authority and responsibility of all level of competent authorities to hold EE activities, reward and promotion of EE, and penal provisions. The TEEA aims to cultivate citizens' understandings of their ethical relationship with the environment, while improving their knowledge, skills, attitudes, and values with regard to environmental protection. In addition, the TEEA also encourages citizens to cherish the environment and take action to achieve sustainable development.

\section{3) The key factors of the TEEA}

There are two important regulations in this Act. One is that, according to Article 19, agencies, public enterprises and organizations, schools, and juridical associations who derive more than 50 percent of their income from government donations shall annually deliver no less than four hours of EE for their staff members, employees, and students, and assign personnel to be responsible for EE. The other is the arrangement of professional certification. According to Article 10, the Environmental Protection Administration in Taiwan (hereinafter referred to as "EPA") and the related central government agencies, such as the Ministry of Education, shall arrange the professional certification for EE institutes, EE facilities and places, as well as EE professional personnel.

\section{4) The approaches of the TEEA}

The TEEA offers working plans, funding, and certification programs as effective approaches to implement EE.

(1) Working plans: the National Environmental Education Framework and Environmental Education Action Plan were established along with the TEEA. In Article 5, Chapter 2, the EPA shall establish the National Environmental Education Framework and propose the framework to the Executive Yuan of Taiwan to implement national EE policy. This framework shall be revised every four years.

(2) Funding support: The EPA of the central government and Environmental Protection Bureau of the local government shall establish an EE fund to deal with EE-related activities and events, such as EE lectures, EE teaching materials, the international EE experiences exchange workshops, environmental education activities, subsidies for EE projects, and training EE personnel. The sources for this fund may be: at least 5 percent of the budget for the annual environmental protection fund; 10 percent of annual revenue from selling recycling waste; 5 percent of revenue from environmental protection fines; interest from the fund; and donation from NGOs, private enterprises, organizations, or institutes.

(3) Certification programs: The TEEA has certification programs for EE Professional Personnel who can be certified through one of six approaches, including education, experiences, expertise, recommendation, examination, and training. EE facilities and places are required to hire at least one certified EE Professional Personnel, and EE Institutes are to offer training for EE Professional Personnel certification.

\section{5) Important outcomes of the TEEA}

(1) All government officials, school teachers, staff, and students, as well as all employees hired by nation-owned enterprises are required to engage in EE programs for at least 4 hours annually.

(2) The TEEA was established and put into effect starting in 2010, and up to August of 2018, there were a total number of 12,067 personnel, 170 facilities \& venues, and 29 training institutes acquiring the badge through verification in Taiwan.

\section{6) Summary}

According to Article 1 in this Act, this Act is formulated to promote EE and cultivate environmentally aware citizens and environmental studies communities to achieve sustainable development. TEEA is an act to foster people's interest in environmental and sustainability issues. Also, there are six perspectives that describe why the TEEA is important, listed below (Wu, 2010):

(1) Let environmental protection concepts and environmental issues understood.

(2) Use the media to spread the word, increasing civic participation 
(3) Improve the administrative efficiency of governments

(4) Enhance the professional capacity of EE of employees in the government

(5) Encourage different agencies, enterprises, organizations, and institutes to participate in the EE field

(6) Strengthen EE courses in schools and EE personnel trainings

In conclusion, based on the EE foundation established by the Taiwan government over many years, the TEEA has improved the quality of EE and encouraged civic participation recently.

\section{Environmental Education Promotion Act in Korea}

Korea (Republic of Korea: South Korea) is one of eight countries with a national EE act. Korea is the third country to have enacted national EE legislation, following the 1990 National Environmental Education Act in the U.S. and the 2003 Act on Promotion of Environmental Conservation Activities through Environmental Education in Japan.

The Environmental Education Promotion Act of Korea (hereinafter referred to as "KEEPA") was enacted in 2008. Since then, the KEEPA has worked as an influential legal framework for EE policy and has provided legal and legislative instruments for EE in Korea (Kim and Krasny 2018). The KEEPA is aimed at promoting EE and ultimately sustainable development by supporting formal (K-16) and non-formal EE.

The legislation process for the KEEPA in Korea started in the early 2000s, based on increased needs of legislative support for environmental educators and the example of the National Environmental Education Act (1990) in the United States. The draft bill was prepared through close collaboration among experts in the Korean Society for Environmental Education (hereinafter referred to as "KOSEE") and the Environmental Forum of Korean National Assembly. The draft bill was revised through pre-legislative consultation between the Ministry of Environment, the National Assembly, and EE experts. The opinions from environmental educators in communities and schools were gathered through KOSEE and the Environmental Forum of Korean National Assembly to influence lawmakers. The draft bill, however, did not pass during the 16th National Assembly, which ended its term in 2004. The KEEPA bill was re-proposed to the 17th National Assembly in 2007 and enacted in 2008. The Presidential Decree and the Ordinance of Ministry of Environment for the Environmental Education Promotion Act were enacted in 2008.

The KEEPA provides legal and legislative instruments for EE in Korea. It also states a legal definition of Environmental Education: "education to help the nation cultivate knowledge, capacity, attitudes, values, and so on which are necessary for preserving and improving the environment and putting such knowledge into practice, with the purpose of contributing to the sustainable development of the State (nation) and the local communities" (Article 2, KEEPA).

The KEEPA of Korea has provisions on support for EE in schools (Article 9) and promotion of non-formal EE (Article 10) along with national/regional comprehensive plans on EE (Articles 5 and 6). Major components of KEEPA include:

- Formulation and implementation of Comprehensive Plans on EE (Articles 5 to 6)

- Establishment and operation of Environmental Education Promotion Committee (Article 7)

- Support for EE in schools (Article 9)

- Promotion of non-formal EE (Article 10)

- Training and certification for non-formal environmental educators (Articles 11 and 12)

- Development and distribution of EE programs (Article 13)

- Certification of EE programs (Articles 14 and 15)

- Designation of Environmental Education Centers (Article 16)

In the KEEPA, the Ministry of Environment is intended to play a collaborative role with other central administrative agencies. Most important, the Minister of Environment shall formulate comprehensive plans on EE in consultation with the relevant central administrative agencies, including the Minister of Education in supporting EE in schools and the Minister of Oceans and Fisheries in supporting marine EE (Article 5).

Another key component of KEEPA is the establishment of the national and regional EE centers to implement and support EE at the national and regional level. According to the KEEPA, the Minister of Environment may designate EE centers to promote the projects necessary to vitalize EE (Article 16), and governors of the 17 provinces or 
metropolitan cities may designate a regional EE center to support EE in the region. Certification systems for nonformal environmental educators (Article 11) and EE programs (Articles 14and15) are also included in the KEEPA. To support the implementation of the KEEPA and to promote EE in their regions, all 17 regional governments have enacted ordinances for EE promotion.

The KEEPA includes both the support for EE in schools (Article 9) and the promotion of non-formal EE (Article 10). Thus, the national/regional EE plans and national/regional EE centers are supposed to cover both formal and non-formal EE. In reality, as EE policies in the school system, the National Curriculum promulgated by the Ministry of Education or ordinances for school EE by regional offices of education are more influential to formal EE . In short, the KEEPA covers both formal and non-formal EE, whereas other policies such as the national curriculum mainly influence formal EE.

\section{Comparison of EEAs in the three countries}

Comparing the provisions of the EEAs in the three countries, we have recognized the following characteristics for each country. Firstly, compared with the Taiwan and Korean Acts, the Japan Act has many articles, and most of them are in "Chapter III Promotion of Environmental Conservation Activities by Citizens". The Japan Act is characterized by the fact that opportunities for citizens to participate in environmental conservation activities and EE are voluntary. The Taiwan administration takes initiative to promote EE in the overall framework of the Act. The Taiwan Act is characterized by the fact participation in the EE program is made compulsory, and it stipulates the subjects, method of learning, number of hours, facilities and places, etc. (Article 19), and also clarifies the financial resources and their uses (Articles 8 and 9). In case of a breach of the Act, it also states the penalty (Article 24). The Korean Act clearly places more focus on non-formal education in the law than that of Japan and Taiwan, and it is characterized by the fact that it tries to find an appropriate balance between both $\mathrm{EE}$ in schools and non-formal $\mathrm{EE}$. In addition, it features provisions for the development and certification of EE programs.

Comparing the EEAs in Japan, Taiwan, and Korea, the most important difference is the presence of legally binding laws. That is, the Act generally uses non-binding language such as "Strive to" in Japan, while the Act more commonly stipulates obligations with language such as "To do" in Taiwan and Korea. Although the Taiwan Act has provisions that show financial backing, the Korea Act does not.

Table 2 is to compile the comparative results of EEAs among three countries. The comparative items in each country are as follows; core organization for promoting EE, legal binding for EE, financial resources for legal binding of EE. It is considered that these would be useful as a viewpoint for comparing and analyzing EEAs in the future.

Table 2 Similarities and differences in EEAs of Japan, Taiwan and Korea

\begin{tabular}{|l|l|l|l|}
\hline & $\begin{array}{l}\text { Core organization for promoting } \\
\text { EE }\end{array}$ & Legal binding for EE & $\begin{array}{l}\text { Financial resources for legal } \\
\text { binding of EE }\end{array}$ \\
\hline Japan & Citizen, civic group & Not included & Not included \\
\hline Taiwan & Government & Included & Included \\
\hline Korea & Government & Included & Not included \\
\hline
\end{tabular}

\section{Conclusion}

Concluding the comparison of the articles in the EEAs in Japan, Taiwan and Korea, the results suggest a hypothesis that there are differences in the roles of the administrations in promoting EE in the three countries. In other words, although the administrations in the three countries play a major role in making opportunities to participate in EE programs, the administration of Taiwan is a facilitator, and the administrations of Japan and Korea are supporters. In addition, there is also a difference in the supporting roles between Japan and Korea. While Korea regards the administration as a main supporter, Japan presumes building collaborative support systems with citizens and private organizations. Therefore, the role of the administration of Japan is limited to logistic support. 
Based on the above analysis, we would like to raise two possible directions for research in the future. Firstly, we will try to compare the roles of environmental administration in each country, with a focus on the management of EEAs by the state and the local governments, and on the relationships between the administration, companies, NGOs, schools, and citizens, etc. Then, we will be able to clarify the characteristics and the challenges of the EE administration in each country. Secondly, we need to consider different factors for the roles of EE administrations in the three countries, using historical, cultural, political, and economic perspectives.

\section{Notes}

1) The eight countries that have enacted the Environmental Education Acts as of 2019 year are the United States, Brazil, Japan, Korea, Philippines, Taiwan, Colombia, and Armenia.

2) The Environmental Education Acts of Japan, Taiwan, and Korea in English notation refer to the following websites. Act on the Promotion of Environmental Conservation Activities through Environmental Education (Japan) referred to "Japanese Law Translation" http://www.japaneselawtranslation.go.jp/ (2018/07/29). Environmental Education Act (Taiwan) referred to "Laws \& Regulations Database of The Republic China" http:/law.moj.gov.tw/Eng/index.aspx (2018/07/29). Environmental Education Promotion Act (Korea) referred to "NATIONAL LAW INFORMATION CENTER" http://www.law.go.kr/LSW/eng/engMain.do (2018/07/29).

\section{References}

Japan Institute of Business Law. 2017. 2016 Fiscal Year Collection Analysis Services Reports of Basic Problems That Commonly Exist in Environmental Legislation in Other Countries: Part1 Environmental Rights /Basic Problem Relations (Environmental Education) / Preventive Principles Relations. Tokyo: Japan Institute of Business Law. (in Japanese).

Kim, C., and Krasny, M. 2018. Environmental Education (EE) Policies in Korea: Institutionalization and Implementation of EE at National and Regional Levels. Korean Journal of Environmental Education. 31(4): 377-390.

Ota, E. 2009. Comparative Analysis of the Environmental Education-related Laws and Acts in the Republic of Korea, Japan, Brazil, and the United States. Nihon KankyouKyouiku Gakkai KantouShibunempou. (4):23-27. (in Japanese).

Ninomiya-Lim, S., Sakurai, R., Kim, C., Chang, T., Lee, S.-K., and Furihata, S. 2017. Sharing, Comparing, and Developing Environmental Education in Asia: For the Journey to be Continued. Japanese Journal of Environmental Education. 26(4):77-83.

Takahashi, M., and Imura, H. 2005. A Comparative Analysis of the Institutionalization Process of Environmental Education in Japan, South Korea, and China. Japanese Journal of Environmental Education. 14(3):3-14. (in Japanese with English abstract).

Wu, L.C.2010. A Cross Comparative Study of Environmental Education Acts of Taiwan and Other Countries. Master thesis, Graduate Institute of Environmental Education, National Normal Taiwan University, Taipei City, Taiwan. (in Chinese). 